\title{
Pendampingan Usaha Beternak dan Pengolahan Daging Ayam Pada Kelompok Peternak Unggas Di Desa Truwai Kecamatan Pujut Kabupaten Lombok Tengah
}

\author{
Syamsuhaidi, Dwi K. Purnamasari*, Tapaul Rozi, Sukirno, dan Firmansyah \\ Fakultas Peternakan Universitas Mataram, Jl. Majapahit No. 62 Mataram 83125
}

\section{Article history}

Received: 29 Agustus 2019

Revised: 20 November 2019

Accepted: 28 November 2019

*Corresponding Author:

Dwi K. Purnamasari,

Fakultas Peternakan

Universitas Mataram,

Mataram, Indonesia

Email:

dwi.kusuma@unram.ac.id

\begin{abstract}
Truwai village, Pujut subdistrict, Central Lombok, is a village that has been designated by government of West Nusa Tenggara provincy as Poultry Village in December 2014. Truwai village has a strategic geographical position because it is close to the superior tourism area of Kuta and the Mandalika Special Economic Zone (KEK Mandalika). Based on the potential of the Truwai village, the Truwai village government has a program to increase the efforts to raise domestic poultry and promote the processing of domestic poultry to produce a superior commodity from Truwai that can be used as a souvenir for tourists. The assistance activities for poultry farming and chicken meat processing training in the Truwai village community aim to increase knowledge and skills in developing the business. The assistance and training activities were carried out for 5 days in the form of discussions and training in making shredded meat, Truwai grilled chicken, chicken satay and sausage and nuggets. The result of the activity showed the high enthusiasm of the community in following and processing chicken meat from the beginning to the packaging. The community expects this assistance activities to continue to be skilled and able to market their products independently.
\end{abstract}

Keywords: assistance; training; farming; processing; chicken meat

Abtrak: Desa Truwai Kecamatan Pujut Kabupaten Lombok Tengah, merupakan desa yang telah ditetapkan oleh pemerintah Propinsi Nusa Tenggara Barat sebagai Kampung Unggas pada bulan Desember 2014, memiliki posisi yang strategis letak geografisnya karena berdekatan dengan daerah pariwisata unggulan Kuta dan Kawasan Ekonomi Khusus Mandalika (KEK Mandalika). Berdasarkan potensi desa, pemerintah desa memiliki program untuk meningkatkan usaha beternak ayam buras dan menggalakkan kegiatan pengolahan ayam buras untuk menghasilkan suatu komoditi unggulan unggas yang bisa dijadikan sebagai souvenir bagi parawisatawan yang datang. Kegiatan pendampingan usaha beternak unggas dan pelatihan pengolahan daging ayam pada masyarakat bertujuan untuk meningkatkan pengetahuan dan keterampilan dalam mengembangkan usaha. Kegiatan pendampingan dan pelatihan dilakukan selama 5 hari berupa diskusi dan pelatihan pembuatan daging abon, ayam panggang khas Truwai, sate ayam, sosis dan nugget daging ayam. Hasil kegiatan menunjukkan antusiasme masyarakat yang tinggi dalam mengikuti dan mengolah daging ayam dari awal hingga pengemasan. Masyarakat mengharapkan kegiatan ini terus dilakukan hingga trampil dan mampu memasarkan produk secara mandiri.

Kata kunci: pendampingan; pelatihan; beternak; pengolahan; daging ayam. 


\section{PENDAHULUAN}

Desa Truwai Kecamatan Pujut Kabupaten Lombok Tengah, merupakan desa yang telah ditetapkan oleh pemerintah Propinsi Nusa Tenggara Barat sebagai Kampung Unggas pada bulan Desember 2014. Desa Truwai merupakan salah satu desa yang strategis letak geografisnya karena berdekatan dengan daerah pariwisata Kuta dan Kawasan Ekonomi Khusus Mandalika (KEK Mandalika). KEK Mandalika adalah Kawasan yang dipersiapkan sebagai kawasan pariwisata unggulan di Pulau Lombok, Nusa Tenggara Barat. KEK Mandalika memiliki lahan seluas 1.034 hektar yang digarap oleh PT Indonesia Tourism Development Corporate (ITDC), BUMN yang sukses membangun kawasan pariwisata Nusa Dua di Bali. Posisi KEK Mandalika juga terbilang sangat strategis di pulau Lombok, berjarak 30 menit dari Bandara Internasional Lombok dan terbentang pantai-pantai mulai dari pantai Kuta, pantai Seger hingga pantai Tanjung Aan (Kompas, 2017).

Berdasarkan potensi Desa Truwai, pemerintah desa memiliki program untuk mengembangkan desa dalam mendukung program pemerintah memajukan daerah pariwisata di Kabupaten Lombok Tengah. Salah satu program desa yang sedang digalakkan adalah meningkatkan usaha beternak ayam buras dan menggalakkan kegiatan pengolahan produk ayam buras untuk menghasilkan suatu komoditi unggulan unggas dari Desa Truwai yang bisa dijadikan sebagai souvenir bagi para wisatawan yang datang.

Produk olahan yang akan dikembangkan oleh pemerintah dan masyarakat desa berupa abon daging, ayam panggang khas Truwai, sate ayam, sosis dan nugget daging ayam. Ayam yang dikembangkan oleh masyarakat adalah Ayam Arab. Salah satu jenis ayam buras yang banyak dipelihara oleh masyarakat adalah Ayam Arab. Ayam Arab bukan berasal dari Arab Saudi, melainkan berasal dari Belgia. Ayam ini dikenal juga dengan nama Silver Brakel Kriel (Kholis dan Sitanggang, 2003), selanjutnya dinyatakan bahwa dari sisi potensi pasar, permintaan terhadap ayam arab cukup tinggi. Hal ini disebabkan tingkat produktivitas telurnya. Jika ayam kampung produksi telurnya hanya mencapai $30 \%$ per tahun, sedangkan ayam arab dapat mencapai $60 \%$ per tahun dan ditambahkan oleh Darmana dan Sitanggang (2002) bahwa produktivitas bertelur ayam arab cukup tinggi mencapai 6070\%. Hal ini sangat berbeda dengan produktivitas ayam kampung petelur yang berkisar $30-35 \%$.

Ayam Arab mempunyai bentuk yang indah, keindahannya terletak pada bulunya yang memiliki ciri khas. Pada bagian leher depan hingga ke bawah (bagian dada) berwarna bintik-bintik seperti mutiara (Priyono, 2003). Ayam Arab mulai berproduksi pada umur 4.5 -5.5 bulan, sedangkan ayam kampung setelah berumur 6 bulan. Produksi puncak dicapai pada umur 8 bulan (Kholis dan Sitanggang, 2003). Dilihat dari sifat genetik dan karakter fisiknya, Ayam Arab memiliki gabungan dari keunggulan yang dimiliki ayam buras dan ayam ras petelur, serta membuang hampir semua kelemahan kedua jenis ayam tersebut. Hampir semua sifat unggul pada ayam buras, misalnya tahan terhadap penyakit, konsumsi pakan rendah, mampu mengkonsumsi pakan rumahan, dan mudah pemeliharaannya, terdapat pada Ayam Arab. Sementara sifat mengeram yang selama ini menjadi kelemahan ayam buras, sama sekali tidak dimiliki ayam arab, sehingga Ayam Arab dapat bertelur sepanjang tahun dan dapat dibudidayakan secara intensif dalam kandang baterai (Triharyanto, 2001).

Secara umum keunggulan Ayam Arab jika dibandingkan dengan Ayam Buras maupun Ayam Ras Petelur menurut Triharyanto (2001) adalah sebagai berikut : 1) produksi telur jauh lebih tinggi dibandingkan Ayam Buras, bahkan dapat menyamai Ayam Ras Petelur, 2) tidak memiliki sifat mengeram, sehingga dapat dikatagorikan sebagai ayam petelur, 3) konsumsi pakan relatif rendah (80100 g/ekor/hari), selain itu ayam arab dapat mengkonsumsi pakan kualitas rendah 4) relatif lebih 
mampu beradaptasi dengan lingkungan serta lebih tahan terhadap penyakit, 5) pemeliharaannya tidak sulit, 6) kualitas telurnya lebih baik (cangkang telur lebih tebal, ukuran kuning telur yang lebih besar, rasa yang lebih gurih, kandungan protein yang tinggi dengan kadar lemak yang rendah), 7) kenampakan fisik telur mirip dengan telur ayam buras.

Dalam rangka mendukung kegiatan tersebut pemerintah desa melakukan kerjasama dengan Fakultas Peternakan Unram mengadakan kegiatan pendampingan usaha beternak dan pelatihan pengolahan daging ayam hingga pengemasan produk.

\section{METODE}

Kegiatan penyuluhan dan pelatihan pengolahan daging ayam dilakukan di aula pertemuan kantor Desa Truwai Kecamatan Pujut Kabupaten Lombok Tengah dengan jumlah peserta sebanyak 10 orang yang terdiri dari para pemuda dan ibu-ibu Desa Truwai dan disaksikan oleh tokoh-tokoh masyarakat, aparat desa, dan masyarakat desa.

\section{Metode Kegiatan}

Metode kegiatan terdiri dari 2 tahap yaitu:

Tahap I. Penyampaian Materi Budidaya Unggas

Penyampaian materi tentang teknik mengembangkan usaha beternak unggas lokal disampaikan dengan metode diskusi dan tanya jawab serta membahas solusi-solusi dari setiap permasalahan-permasalahan yang ada di masyarakat Desa Truwai.

Tahap II. Praktek pembuatan abon daging, ayam panggang khas Truwai, sate ayam, sosis dan nugget daging.

Praktek dilakukan mulai dari persiapan alat dan bahan, pemrosesan daging, pembuatan bumbu, pemasakan daging, hingga pengemasan produk daging olahan. Peserta dibagi sebanyak 5 kelompok yang terdiri dari 2 orang dan masing-masing kelompok membuat setiap produk dan diberi kesempatan untuk melakukan kreatifitas atau inovasi dari setiap produk yang dibuat.

\section{HASIL DAN PEMBAHASAN}

Berdasarkan hasil kegiatan tahap I, diketahui bahwa peserta antusias mengembangkan usaha beternak ayam, namun dalam menjalankan usahanya ditemukan berbagai permasalahan yang muncul dan solusi-solusi yang dihasilkan yaitu:

1. Di Desa Truwai Kecamatan Pujut sudah terbentuk beberapa kelompok peternak ayam buras tapi nampaknya fungsi kelompok belum terorganisir tentang peranan masing-masing anggota kelompok sehingga informasi-informasi serta bantuan-bantuan dari pemerintah tidak maksimal didapatkan. Peran kelompok peternak sangat penting dalam upaya memudahkan dalam usaha, mendapatkan bantuan informasi, obat-obatan ternak dan pakan, memudahkan dalam penjagaan keamanan, serta memudahkan dalam pemasaran. Kerjasama dengan akademisi akan terus ditingkatkan dalam pendampingan usaha beternak.

2. Selama memelihara ternak ayam buras kendala yang dihadapi adalah masalah penyakit, umumnya peternak kurang mengetahui faktor-faktor penyebab dan cara mengobati penyakit-penyakit pada ayam. Dengan terbentuknya kelompok peternak unggas yang dikelola dengan baik akan memudahkan dalam mendapatkan informasi-informasi dan bantuan obat dan pengobatan dari instansi terkait. 
3. Kurangnya pengetahuan peternak dalam managemen pemeliharaan ternak unggas yang sangat bergantung pada faktor lingkungan, baik kebersihan kandang, suhu dan kelembaban kandang. Masalah berikutnya yang dihadapi oleh peternak adalah masalah pakan. Selama ini pakan yang digunakan adalah pakan komersial yang diperoleh di poultry shop berupa konsentrat, dengan harga relatif mahal. Solusinya adalah peternak harus meningkatkan pengetahuan tentang jenisjenis bahan pakan alternatif yang dapat digunakan dan cara pembuatan pakan, sehingga peternak dapat membuat pakan sendiri dengan harga yang relatif lebih murah, dengan menggunakan peralatan pengolahan pakan yang telah dimiliki namun belum digunakan karena ketidaktahuan dalam pengoperasian. Kegiatan pendampingan berikutnya yang akan dilakukan adalah melatih para peternak mengoperasikan alat-alat yaitu mesin giling, copper, mixer, dan mesin pelet.

4. Pembuatan label dan pengemasan produk olahan ayam buras serta masalah pemasaran yang masih dirasakan sulit, namun peternak dimotivasi untuk menghasilkan produk khas dan berkualitas terlebih dahulu, pemasaran dapat dilakukan secara langsung maupun secara on line dengan bekerjasama dengan berbagai dinas, lembaga, dan organisasi-organisasi masyarakat. Pemerintah desa berjanji akan membantu dalam memfasilitas peralatan pengemasan dan membantu di dalam pemasaran produk-produk olahan ayam buras khas Desa Truwai.

Antusisme peserta kegiatan pengabdian pada Tahap I nampak dari semangat peserta dalam proses tanya jawab dalam sesi diskusi, seperti yang tersaji dalam Gambar1.
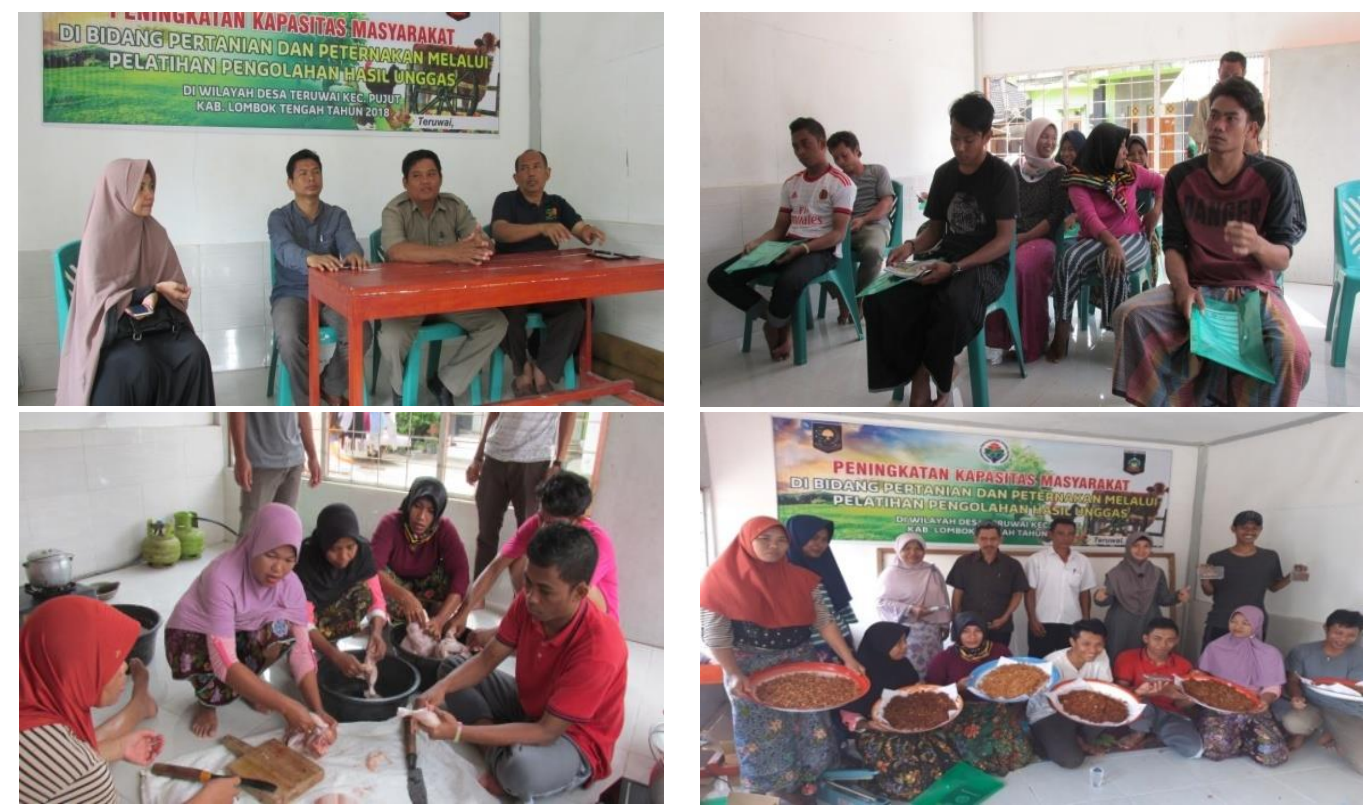

Gambar 1. Suasana kegiatan penyuluhan (atas) dan Suasana Kegiatan Pelatihan (bawah)

Kegiatan Tahap II, adalah melatih peserta pelatihan yang terdiri dari ibu-ibu rumah tangga dan pemuda-pemuda masyarakat Desa Truwai mengolah produk-produk olahan daging ayam buras, yang terdiri dari: pelatihan pembuatan abon daging dengan berbagai cita rasa, pembuatan ayam bakar khas Truwai, pembuatan sate ayam, sosis, dan nugget ayam.

Pengolahan produk ayam buras ditujukan untuk memperpanjang daya tahan dan menjaga serta meningkatkan kualitas hasil produksi ayam agar tidak mudah rusak, sehingga perlu penanganan panen dan pasca panen secara baik. Dalam aturan gizi normal, yang ditetapkan oleh Widya Karya Pangan 
dan Gizi, LIPI tahun 1988, manusia membutuhkan 4,5 g protein hewani asal ternak per kapita per hari. Nilai tersebut dapat diperoleh melalui konsumsi $6 \mathrm{~kg}$ daging, $6 \mathrm{~kg}$ telur, dan $4 \mathrm{~kg}$ air susu per kapita per tahun. Guna memenuhi kebutuhan tersebut, berbagai usaha telah dilakukan untuk meningkatkan produksi hasil ternak. Namun produksi ternak yang tinggi harus diimbangi juga dengan penanganan pasca panen dan pengolahannya sehingga bahan makanan tersebut dapat sampai ke konsumen dalam kondisi yang baik. Dengan proses pengawetan dan pengolahan tersebut, diharapkan nilai gizi bahan pangan hasil ternak dapat dipertahankan, bahkan ditingkatkan.

Kegiatan pelatihan diikuti peserta pelatihan dengan antusias, terlihat dari peserta tekun membaca petunjuk atau resep yang diberikan dan mengikuti tahapan-tahapan proses yang harus dilakukan dalam proses pengolahan daging unggas menjadi abon, ayam panggang, dan sate ayam, serta sosis dan nugget. Peserta pelatihan mendapatkan modul 'Beternak Ayam Buras dan Pengolahan Produk Daging Ayam Buras'. Modul berisi beberapa pokok bahasan yaitu beternak ayam buras, pengolahan produk ayam, dan teknik pengolahan. Teknik pengolahan berisi materi dan metode pembuatan sosis, abon, ayam bakar/goreng khas Truwai, sate, dan nugget. Kegiatan pelatihan selain diikuti oleh peserta juga disaksikan oleh pengurus desa, tokoh masyarakat, dan masyarakat Desa Truwai, seperti nampak pada Gambar 1.

Berdasarkan hasil evaluasi dan pengamatan terhadap proses pelatihan pengolahan produk daging unggas terlihat ada peningkatan pengetahuan, sikap, semangat, dan keterampilan dari semua peserta, masyarakat yang menyaksikan, dan pengurus desa yang termotivasi untuk meningkatkan usaha beternak ayam buras dan pengolahan produk daging unggas sebagai usaha masyarakat Desa Truwai. Peserta termotivasi untuk membuat produk unggulan dan khas Desa Truwai untuk dipasarkan dan dijadikan souvenir untuk parawisatawan yang datang berkunjung ke Pulau Lombok, apalagi peserta sudah mendapatkan pelatihan pembuatan leaflet dan pengemasan produk.

Kegiatan pelatihan ini berjalan dengan lancar dan sukses, dikarenakan dukungan pemerintah desa yang maksimal untuk meningkatkan kemajuan desa dan sumber daya manusianya. Pemerintah desa telah mempersiapkan warganya yang beternak unggas dengan bantuan bibit dan fasilitas kandang, serta pengadaan peralatan pengolahan pakan unggas. Selain itu didukung dari semangat masyarakat desa untuk menambah pengetahuan dan keterampilan dalam berwirausaha, sehingga kelak mampu secara mandiri meningkatkan taraf hidup dan kesejahteraan menjadi lebih baik.

\section{KESIMPULAN DAN SARAN}

Kegiatan pelatihan berjalan dengan lancar dan sukses, peserta pelatihan, pemerintah desa dan masyarakat puas dan senang dengan materi dan keterampilan yang telah diperoleh. Selain itu peserta pelatihan dan pemerintah desa berkomitmen untuk meneruskan dan mendukung meningkatkan beternak ayam buras dan menghasilkan produk-produk olahan yang siap di pasarkan.

Kegiatan ini perlu dilanjutkan berupa kegiatan-kegiatan pendampingan melalui kerjasama antara pemerintah desa dan akademisi.

\section{Ucapan Terima Kasih}

Tim pengabdian mengucapkan terima kasih atas kerjasama Fakultas Peternakan Unram dengan pemerintah Desa Truwai, yang telah mendanai kegiatan pengabdian ini. 


\section{DAFTAR PUSTAKA}

Darmana, W. dan M. Sitanggang, 2002. Meningkatkan Produktivitas Ayam Arab Petelur. AgroMedia Pustaka. Jakarta.

Kholis, S. dan M. Sitanggang, 2003. Ayam Arab dan Poncin Petelur Unggul. AgroMedia Pustaka. Jakarta.

Kompas, 2017. Kawasan Ekonomi Khusus Mandalika. www.kek.mandalika.com (Agustus 2018)

Priyono, E. 2003. Ayam Arab sebagai Alternatif Usaha Ternak Unggas. Suara Merdeka .Jumat, 29 Agustus 2003. (Agustus 2018)

Triharyanto, B. 2001. Beternak Ayam Arab. Kanisius. Yogyakarta. 